\title{
PRACTICAL QUESTIONS FOR SILO BAGS GRAIN STORAGE TECHNOLOGY
}

\begin{abstract}
In enterprises with limited capacities and a low-powered grain drying facilities there is a problem of economical and reliable storage of dry, wet and moist grains. One of the options for its successful solution is the application of grain storage technology in silo bags, tested in many enterprises, the basic principle of which is based on the self-preservation of grain under hermetic conditions in an environment of carbon dioxide. To implement this technology, it is necessary to determine the suitability of the batch of grain for loading in the silo bags on the basis of an operational analysis of the grain quality. After loading the grain, the silo bags are sealed, the grain mass is stored for a certain time and then unloaded.

After many years of industrial testing of grain storage technology in silobags, recommendations have been developed that allow to ensure the quantity and proper quality of grain in the process of implementation of the technology. To do this, it is provided to carry out a whole range of activities - personnel training, the selection and preparation of a storage area for grain, deratization, the determination of the quality of grain at all stages and a safe shelf-life, depending on the condition of the grain, weighing of the grain; loading silo bags and placing them on the site; drawing of marks for identification of silobags; monitoring of the state of silo bags and grain and the restoration of the integrity of the silo bags throughout the storage period; accounting for grain in the silobags; processing of unconditioned grain; object protection, final analysis of the work performed, identify problems and ways to solve them.

The storage site for grain in the silo bags must be cleaned of stubble and grass, sharp objects, grain residues, solid hardwood or the most densely packed soil (the clay surface is undesirable, as precipitation makes imposible laying and unloading of silobags), ensure no stagnation of water during rains and melting snow, provide the possibility of free movement of special equipment on the site. It must be deratized and fenced with a mesh with small openings, a height of at least $1 \mathrm{~m}$ and dipped.

The analysis of the characteristics of three-layer silobags showed that to optimize the storage of dry grain, it is advisable to use the largest silobags of $90 \mathrm{~m}$ in length, since they have a larger capacity, there will be less time spent on dressing and sealing the silobags, saving space between the silo bags lying along one another, there will be less length of silobags to go for tying, as well as saving money on the cost of silobags, the cost of working time and fuel (decreases the number of transfers of special equipment). It is advisable to take into account the possibility of unloading the sleeve during one shift.

At all stages (loading, storage, unloading) the determination of the quality of grain, monitoring the condition and restoring the integrity of the silo bags checking the sanitary condition of the site and the presence of baits should be carried out. Precautions should be observed, grain accounting, working with non-standard grain and final analysis of grain storage results should be carried out.
\end{abstract}

Key words: grain mass, silo bags, storage area, hermetic storage conditions, grain quality

\section{Problem formulation}

In recent years, a significant number of commercial elevators with modern transport and technological equipment for effective post-harvest processing and storage of grain are being built. However, the cost of their services for the main technological operations of cleaning and drying of grain, numerous cases of incorrect display of quality indicators at reception, it is expedient to use the own technological capacities for cleaning and, especially, for the drying of grain, for large and average grain producers. The construction of powerful elevators to meet the requirements of contracts for large quantities of grain during the harvest period is irrational, given the short period of effective operation of equipment throughout the year. Therefore, the problem of economical and reliable preservation of wet and dry grain for further development with the use of its own equipment appears. Such an opportunity is provided by the technology of storage of grain in silo bags, the basic principle of which is to store grain in a sealed environment.

Let's consider the main stages and questions of the practical implementation of grain storage technology in silobags, which are approved and issued as recommendations on grain storage technology in polymeric grain sleeves for the enterprises of LLC "Grain Base of Ukraine".

\section{Work organization}

The process of storage of grain in silo bags includes the following steps:

- determining the suitability of the batch of grain for loading into the silo bags by means of operative determination of grain quality;

- grain loading in silo bags;

- grain storage in silo bags;

- unloading of grain from silo bags.

Managing the process of grain storage in the silo bags is understood as a set of measures aimed at ensuring the quantity and quality of grain that is shipped in accordance with contracts after storage in silo bags. This complex of activities includes:

- training of personnel and bringing the requirements of the complex of measures to all persons involved in the process of grain storage in silo bags;

- selection and preparation of a storage site for

grain;

deratization

- carrying out a complex of measures on

- definition of quality at all stages; 
- determining the safe storage period depending on the condition of the grain;

- weighing of grain;

- loading silo bags and placing them on the site;

- marking for identification of silo bags;

- monitoring of the state of silo bags and grain

and taking measures to restore the integrity of the sleeves during the storage period;

- grain accounting in silo bags;

- unloading of grain from silo bags;

- work with non-conforming grain;

- object protection;

- analysis of the work carried out, determination of problems and ways of their solution.

\section{Selection and preparation of the site.}

The chief of the sector is responsible for the selection and proper preparation of the site for the silo bags storage. The sector chief independently manages the site preparation process or assigns a responsible person from the engineering technical workers.

In preparing the site, the responsible person is guided by the developed methodology, own experience and applies the best known decisions of other organizations regarding this process, in agreement with the company Quality Control Division.

The volume and degree of complexity of work is determined by the responsible person on the basis of the specifics of each individual land plot, available equipment, methods and training of personnel, but ensuring compliance with the site requirements is mandatory.

The choice of the site for storage of grain in the silo bags is made taking into account the following requirements:

- maximum approximation to the territory of the enterprise (elevator, grain reception enterprise);

- the correspondence of the coating (hard coating, soil, clay surface is undesirable, as it is impossible to pack and unload the grain during precipitation);

- absence of stagnation of water during rains, melting of snow or the possibility of draining water from the zone of silo bags placement;

- the possibility of the movement of special equipment, which is planned for packing and unloading of grain from the silo bags between the elevator and the site, as well as the possibility of movement of special equipment on the site.

The preparation of the site includes the following steps:

- cleaning the surface from stubble, stones and other sharp objects that can damage the silo bag; grass clearing with Glyphosate or similar; clearing of all the remnants of grain that can attract rodents; solid surface;

- sealing with a roller to create a maximum

- conducting a site deratization (in detail the process of deratization is described below);

- fencing by the grid with a small apertures close to the ground (digging / grafting) to a height of not less than $1 \mathrm{~m}$ to prevent the foxes, dogs and other animals from entering, which may damage the silo bags.

The chief of the laboratory is obliged to inform the Quality Control Department about the stages of preparation of the site as they are carried out and on the complete preparation of the site for placing the silo bags by e-mail and telephone.

Deratization. Responsible for the proper conduct of deratization at all stages is appointed by the chief of the sector. For deratization it is expedient to use readymade preparations with prolonged action in the form of individual briquettes (paraffin-grains, dough, etc.) intended for mass deratization of open territories. Unacceptable self-preparation of lures from improvised raw materials using liquid pesticides, and the use of lures on the basis of loose grains.

\section{Deratization is carried out in several stages:}

- deratization of the site is carried out by the selected way after preparation of the surface, taking into account the manufacturer's instructions and safety rules;

- deratization while the silo bags packing: decomposition of lure under the silo bag in the process of laying out at the rate of $1 \mathrm{pc}$. at $3 \mathrm{~m}$; decomposition of lure around perimeter of silo bag at the rate of $1 \mathrm{pc}$. at 3 $\mathrm{m}$;

- checking the availability of lures in the process of storing and applying it as necessary.

Conduct of deratization is fixed in the work log of the responsible person and F66 in the laboratory of the sector, for the responsible person it is possible to use the $\log$ F135 (Log of the volume of performed works on deratization).

Decomposition of lure is carried out only with tweezers in mittens. Under winter weather, the bait should lie on the surface of the snow and be accessible to rodents. The lure "Rodent Death" is effective at temperatures higher than $-15^{\circ} \mathrm{C}$. Additional use of lures prepared by local sanitary nurseries, as well as other drugs with proven efficacy, is allowed, especially in winter. The head of the laboratory is obliged to inform the Quality Control Department about the stages of deratization as they are conducted by e-mail.

Characteristics of silo bags. Typical silo bag sizes are as follows: length 60, 75, 90 meters. The diameter may be $1.83 \mathrm{~m}, 2.44 \mathrm{~m}, 2.74 \mathrm{~m}, 3.05 \mathrm{~m}, 3.66 \mathrm{~m}$. The most common silo bags are $60 \mathrm{~m}$ in length, $2.74 \mathrm{~m}$ in diameter and 200 tonnes in wheat. This is due to the fact that from this size the common usage of silo bags began for the first time. And at the moment, most of the machinery in the parks of grain producers is tailored for this particular diameter. The length of the silo bag may be different. At the moment, some firms offer length of silo bags for special request. To optimize the storage of dry grain in polymeric sleeves it is advisable to use sleeves with a length of $90 \mathrm{~m}$. This is primarily due to the time spent on the loading and unloading of grain. Since the sleeve of 90 meters in length has a larger capacity, loading of the same amount of grain into such silo bags take less time (less time spent on the fixing and sealing of the silo bag during loading, and less time spent preparing for the unloading of grain. In addition, in conditions of limited space, the usage of 90-meter silo bags will save space required for indents from the first to 
Table 1 - Calculation of cost savings due to the greater length of the silo bags

\begin{tabular}{||c||c||c||c||c||c||c||c||c||}
\hline $\begin{array}{c}\text { Grain } \\
\text { quantity } \\
\text { for } \\
\text { bagging, } \mathrm{t}\end{array}$ & $\begin{array}{c}\text { Silo bag } \\
\text { lenght, } \\
\mathrm{m}\end{array}$ & $\begin{array}{c}\text { Silo bag } \\
\text { capacity, } \\
\mathrm{t}\end{array}$ & $\begin{array}{c}\text { Required } \\
\text { amount of } \\
\text { bags, pc. }\end{array}$ & $\begin{array}{c}\text { Average } \\
\text { cost of } 1 \\
\mathrm{~m} \text { of bag, } \\
€\end{array}$ & $\begin{array}{c}\text { Length of the } \\
\text { bag required } \\
\text { for an tying, } \\
\mathrm{m}\end{array}$ & $\begin{array}{c}\text { The total length is } \\
\text { needed to tie the } \\
\text { bags, } \mathrm{m}\end{array}$ & $\begin{array}{c}\text { The cost of } \\
\text { the part of the } \\
\text { sleeves for } \\
\text { tying, } €\end{array}$ & $\begin{array}{c}\text { Saving, } \\
€\end{array}$ \\
\hline \hline \multirow{3}{*}{11000} & 60 & 200 & 55 & 9,08 & 5 & $55 \times 5=275$ & 2497 & - \\
\cline { 2 - 11 } & 75 & 250 & 44 & 9,00 & 5 & $44 \times 5=220$ & 1980 & 517 \\
\hline \hline & 90 & 300 & 37 & 9,11 & 5 & $37 \times 5=185$ & 1685 & 811 \\
\hline \multirow{3}{*}{55000} & 60 & 200 & 275 & 9,08 & 5 & $275 \times 5=1375$ & 12485 & - \\
\hline & 75 & 250 & 220 & 9,00 & 5 & $220 \times 5=1100$ & 9900 & 2585 \\
\hline
\end{tabular}

the second silo bag, lying along one another. For example, with a length of $220 \mathrm{~m}$, an additional $7 \ldots 10 \mathrm{~m}$ space can be saved, which can accommodate 38 tons of grain (with the usage of silo bags in diameter of $2.7 \mathrm{~m}$ ) or 47 tons of grain (provided the usage of silo bags of $3.0 \mathrm{~m}$ in diameter).

The use of 90-meter silo bags also allows you to save money on the cost of silo bags, the cost of working time and fuel (decreasing the number of crossings). When using silo bags 5 linear meters go to tie at the beginning and at the end ( $2.5 \mathrm{~m}$ each side). Accordingly, the larger the number of silo bags - the more linear meters goes to their tied up. So, the 90-meter silo bags, again, allow optimizing the length of the fastening.

Below is a table that shows that the most advantageous in terms of cost savings is to use sleeves with a length of 90 meters.

However, it should be noted that from the point of view of the convenience of packing and selection of grain, it is most expedient to use silo bags of medium length. Such silo bags are more likely to be enclosed or taken within one day without leaving the open silo bag for another shift, and the quality indicators will be determined accordingly with greater accuracy.

Composition and physical properties of silo bags. Three-layer polymer silo bags are a modern hightech product, manufactured by three-layer extrusion with a layer-differentiated modification. The unique combination of polymers and special additives of the new generation provides silo bags with elasticity, softness and resistance to UV exposure. Polymer silo bag consists of three inseparable layers: an external white layer that provides reflection of light and prevents the heating of the mass inside the silo bag and two internal black layers that make the silo bag strong and absolutely light proof. In addition, all layers contain a special additive - a stabilizer that protects the film from the destructive effect of ultraviolet rays.

Plastic bags are made of exclusively primary raw materials due to the high quality requirements. This increases the operational quality and durability. Highquality polyethylene LLDPE / LDPE-MDPE / LLDPE is used for production of sleeves. The main difference between different types of polyethylene is the way of their cellular structure, as the molecules are interconnected with each other and how tight they are formed.
Linear low density polyethylene (LLDPE) is the most flexible of plastic films. LLDPE is a mixed form of LDPE, where the film has much greater flexibility, tensile strength and a higher adhesion density of molecules. It is more flexible and soft. LLDPE is often blended with other types of films, which gives them greater flexibility and added strength. LLDPE is used for films that require enormous strength to absorb shocks, prevent gaps and punctures. All of the molecules are aligned and firmly joined together when the film is stretched.

Low density polyethylene (LDPE), due to its flexibility, fits well with different surfaces. The disadvantage is that LDPE is not as strong or dense as some other types of plastic coatings. $\mathrm{He}$ is not so resistant to puncture.

Medium density polyethylene (MDPE) is the least common form of polyethylene for flexible plastic coatings. Its positive properties are that it is stronger than LDPE and has somewhat higher chemical resistance. It has a more dense structure of the cell, which makes it more resistant to tearing and puncture.

Polyethylene of high density (HDPE, also HD) differs in that it is the strongest, hardest, most chemically stable and the least flexible of four types of flexible plastic film. The strength of HDPE comes from its dense molecular structure, which complicates the passage of other molecules through its structure at the microscopic level. But this kind of polyethylene for the production of silo bags is not used.

The world's largest operators of silo bags market are the following companies:

1. Ipesa

2. Gem Silage Products

3. Rkw Group

4. Bagman Llc

5. Canadian Tarpaulin Manufacturers Ltd

6. Grain Bags Canada

7. Silo Bags International

8. Grain Storage Solutions

9. Quality Crops

10. Temudjin Flex-PackBv

11. Brain Chamber Polysacks Pvt.Ltd

12. Grainpro Philippines

«Planet Plastic» is the only Ukrainian manufacturer of plastic silo bags. Bags are sold under the trade mark TM «Harwell». 
Table 2 - Physical properties of films of different manufacturers

\begin{tabular}{|c|c|c|c|c|}
\hline \multirow{2}{*}{ PROPERTIES* } & $\begin{array}{c}\text { BUDISSA } \\
\text { BAG }\end{array}$ & $\begin{array}{l}\text { BUDISSA } \\
\text { X-TREME }\end{array}$ & $\begin{array}{c}\text { GREEN } \\
\text { BAG }\end{array}$ & $\begin{array}{l}\text { BAGS } \\
\text { HITEC }\end{array}$ \\
\hline & Germany & Germany & Spain & Greece \\
\hline Film thickness, micron & 230 & 170 & 240 & 240 \\
\hline Layers, pc. & 3 & 7 & - & 3 \\
\hline Tensile Strength MD (at Break), N/mm² (Mpa) & $\geq 27$ & 40 & 23 & 38 \\
\hline Tensile Strength CD (at Break), N/mm² (Mpa) & $\geq 30$ & 40 & 23 & 37 \\
\hline Elongation MD (at Break), \% & $\geq 850$ & 600 & 900 & 550 \\
\hline Elongation CD (at Break), \% & $\geq 950$ & 700 & 925 & 600 \\
\hline Dart Drop, $\mathrm{g}$ & $\geq 950$ & - & $>900$ & - \\
\hline Flat, $g$ & - & 1300 & - & - \\
\hline O2- Permeability, $\mathrm{cm}^{3} /\left(\mathrm{m}^{2} \cdot \mathrm{d}\right)$ & $<250$ & - & - & - \\
\hline UV-Stabilization, year & 2 & 2 & 2 & - \\
\hline
\end{tabular}

* Quality parameters are provided by the manufacturers

Determination of grain quality at all stages. The head of the laboratory of the sector is responsible for the proper determination of the quality and completion of the relevant documentation. Quality determination is carried out at all stages of the grain storage process in the silo bags to ensure process control.

\section{Stage of grain bagging.}

At this stage, grain samples are taken from each transport unit, which is sent for loading into the silo bags. For each silo bag, an average sample is individually formed to determine the quality of the grain. After loading the silo bag, a complete analysis of the sample is carried out with the results recorded in the "Journal of observation of grain stored in warehouses and in silos of the elevator" (F66) and in the summary table. Determining the quality of the grain makes it possible to establish the period of its safe storage and to investigate changes in the quality indicators that occurred during the time the grain stayed in the sleeves.

\section{Stage of grain storage.}

Sampling of the bags is an undesirable operation, which causes damage to the film of the silo bag, and therefore is allowed only with real need. The exception is the silo bags with moist and wet grain, in which you need to take samples with a certain frequency depending on the risks (humidity). Sampling is carried out at 5 points at different heights using a double-tube sampling spear with a diameter of $3.5 \mathrm{~cm}$ by puncture without preliminary incision. When sampling, it is advisable to measure the temperature of the grain of the upper, middle and lower layers of grain in the sleeve and determine the organoleptic characteristics of the grain. After sampling and temperature measurement, the technician immediately seals the hole with a special tape. The data of the complete analysis, temperature and organoleptic indicators are logged into the form № 66 .

Stage of unloading (extraction) of grain. At this stage, the determination of humidity is carried out on the moisture meter, smell, and the appearance of the grain is evaluated to establish the quality condition of the lot. Depending on the results of this analysis, further movement of the grain occurs. Each transport unit is analyzed, an average sample is formed along the silo bag, followed by a complete analysis. The data for each sleeve are logged into the F66 and into the summary table.

Weighing the grain. When moving the grain into and out of the silo bags weighing is carried out, if there are possibilities of the technological process.

Loading silo bags and placing them on the site. When receiving sleeves, check the certificates for the products, the date of manufacture, the shelf life. Prior to downloading, responsible personnel from the engineering technical workers are developing a plan for silo bags placement. The loading of the silo bags takes place according to the placement plan approved by the Head of the sector. Moist and dry grain is placed in separate arrays. It is advisable to place the dry grain in bigger and wet in smaller arrays. Moist grains are packed into the silo bags after a high quality combine cleaning with a content of foreign impurities no higher than $1.0 \%$ to prevent premature damage corn. It is advisable to put dry grain in the silo bags with a content of foreig impurities no higher than $1.0 \%$ for the possibility of overloading under the contract without additional purification. The cleaning mode before loading in the silo bags is determined depending on the peculiarities of the technological process of each individual enterprise. The handling of baggers is carried out in accordance with the manufacturer's instructions.

\section{Way of silo bags placing.}

Along the grain loading line, a rope is stretched to support the co-distribution of the grain bagging machine and tractor movement, as well as the parallelism of moving the grain cart and the grain bagging machine while bagging. When unpacking the sleeve, the responsible person takes the plastic repare tape that comes in the kit, and at the end of the shift takes it to the 
laboratory for further use to seal the holes and damage. The recommended distance of $2 \mathrm{~m}$ between the two silo bags or $5 \mathrm{~m}$ between the central axes of the silo bags (stretched rope), starting from the diameter of the sleeve $2,75 \mathrm{~m}$ and the possibility of stretching at loading up to 3 $\mathrm{m}$. If necessary, a technical gap between the rows of silo bags of $10 \mathrm{~m}$ for the ability to drive cart and grain extractor. It is advisable to make such gaps between the pads of raw and dry grains and individual arrays.

There are two ways to close the silo bag with its sealing: by simply tying it and by using two boards. With the folded end of the grain bag positioned between the two boards, fasten the boards together. Flatten the end of the bag, roll the sealed end downward a minimum of three times. Whatever way you come up with fold the end underneath the grain bag as far as possible.

Regardless of the method chosen for closing the silo bags, it is necessary to ensure sufficient tightness and reliability of the closure. For this, it is strongly recommended not to overload the silobags. Also, before starting to load grain, it is necessary to check the presence of boards of appropriate quality, rope, seals. To close the silo bag with the condition of rational use of its volume, you must leave $2.0 \ldots 2.5 \mathrm{~m}$ of the sleeve film free. Silo bags are sealed by placing tightened seals on fastened boards or a knotted end of the silo bag. The numbers of the seals are recorded in the working logs of the guard, the senior master. The beginning of the next silo bag is placed at the end of the previous one, thereby compacting the end of the silo bag. At the end of the silo bag loading, the person responsible at the site informs the laboratory about the end of loading and the beginning of loading the next silo bag for the formation of laboratory samples as accurately as possible. Also, the laboratory is told which cart to which silo bag was unloaded at the end and at the beginning of the next silo bag loading.

At the end of the shift, the remains of placer grain are carefully removed from the loading area of the silo bags to prevent from attracting rodents. As loading is completed, a map of the silo bags is filled in, indicating the placement of each silo bag on the site, its number, loading date, and the main quality indicators (humidity, foreign and grain impurities). Every day, when working with grain, the Chief of laboratory fills in a summary table, in which, in addition to quality indicators, the ambient temperature is recorded. The map of the silo bags and the final table are weekly electronically sent by the Chief of the laboratory to the quality department.

The responsible person numbers the silo bags in sequence numbers as they are loaded with indelible paint at the beginning of the silo bag on one side and at the end of the silo bag on the other side. The number is used to identify the silo bag, display the quality data in the F66, the silo bags map and the final table.

Monitoring the condition and taking measures to restore the integrity of the silo bags during the storage period. The person appointed by the head of the sector is responsible on the preservation and maintenance of the integrity of the sleeves, the correct and timely repair of damage, the organization of sewage waters. The bypass of the site by the responsible employees of the enterprise is carried out as necessary, but at least once a week (for this it is advisable to determine the day of the week). Silo bags are inspected on the subject:

- the integrity of the film;

- rodent damage and the presence of poisonous

baits;

- presence and damage of seals (selectively).

In the event of damage, they are eliminated depending on the cause and extent of the damage:

- damage to a small size (from rodents, hail, etc.) need to be cured with a special adhesive tape crosswise. It should be noted that, at low temperatures, the tape becomes brittle. To restore its properties, it needs to be warmed up (in hands, pockets, etc.);

- with a strong overload of the silo bag the appearance of black stripes is possible on its surface . They need to be cured with several strips of tape over the strips to prevent breaking; allowed.

- close small damages by mounting foam is

Each case of silo bag damage is fixed in the working $\log$ of the responsible worker and in the F66 with the designation of the cause of the damage.

The laboratory once a week checks the work to maintain the integrity of the silo bags, the sanitary condition of the site and the presence of lures. Detected discrepancies are issued by service notes to the the Head of the sector, a copy - to the Quality Control Department.

Grain accounting in silo bags. Raw grain accounting, which is stored on the field, is maintained in the workbook by a senior technologist responsible for the bagging process. He provides timely information to all involved departments in electronic form. In this case, the weight of the batch is taken conditionaly by the number of loaded silo bags and converted into physical weight when entering the elevator by weighing and posting.

The batch of dry grain loaded in the silo bags is part of the total number of weight in the context of crops. Accounting is carried out by accounting and laboratory as an internal movement of grain, which displays the date, weight and quality.

Unloading grain from silo bags. When extracting grains from the silo bags, the responsible technologist / master of the enterprise shall ensure that the mixing of grain from the beginning of the sleeve and / or the lower raw layer of grain with the conditioned batch is prevented. He makes a timely decision to use manual labor for the precise unloading of moist and damaged grains. Timely notifies the laboratory about the presence of such grains and which vehicle it is loaded with. Each case of the presence of moist, spoiled or damaged grains in the silo bags immediately fixes in the working log, indicating the cause of the appearance of such a grain. This information is transmitted to the laboratory. It is unacceptable to download non-standard grain into the cart. For these needs, duty trucks are used.

Work with grain that needs additional processing. The head of the laboratory is responsible for the analysis of grain for spoilage, which is carried out very carefully to prevent the irrational use of energy and equipment to bring the batches to standard.

Grain that needs additional processing - grain that partially lost its appearance due to unfavorable storage conditions with high humidity, and / or not a healthy grain with a smell, as well as a partial mildew of 
mildew requiring healing. For such a grain, depending on the degree of damage, there are several ways of healing:

- the grain with a slight unusual for a healthy grain odor is directed to ventilation by atmospheric air through a dryer or a storage vented hopper;

- grain with a more stable smell is sent to heat drying. The temperature of the heating of the grain should not be higher than $25 \ldots 35^{\circ} \mathrm{C}$ to prevent the grain from over drying;

- if the smell of grain is very stable, under favorable weather conditions, it is advisable to place the grain on an open area for sun drying;

- when it is impossible to bring the grain to the quality indicators, allow the shipment of grain under the contract by mixing in small quantities to the main batch;

- the decision on the implementation of this party on the internal market in accordance with the established procedure is considered.

Protection of the object. Under the condition of grain storage on the territory of the enterprise (elevator), the protection of the grain stored in the silo bags is carried out in the general order of maintenance of safety.

Under the condition of storage outside the territory of the enterprise, the protection of the silo bags is provided by the department of the protection of the region. Thus, the area of 17 hectares (Pavolotskaya area) is provided by fencing along the perimeter of a grid with a small aperture and one upper layer of barbed wire, which provide a total height of the fence to $2,0 \mathrm{~m}$. In addition, portable lighting is assumed. The number of guards is regulated and provided by the head of the guard. Guards are present at the time of loading, and the extracting of grain. They are responsible for the quantity, the overall integrity of the loaded silo bags from mechanical and sabotage damage and the presence, integrity, inspection of seals. A record in the guard's work log (date, site, crop, number of silo bags, their numbers and seals numbers) is made by the duty guard, and then information transfer to the next shift.

Analysis of the work done. Identification of problems and ways to solve them. As the grain is unloaded from the silo bags, the information is accumulated in the summary tables. The data obtained during the work with the silo bags, are thoroughly checked and analyzed by the Quality Control depertment, Heads of the sectors, Chiefs of laboratories. The methods of work of sectors are considered for the purpose of revealing and identifying new non-standard solutions and best practices of work with silo bags.

\author{
М. Желобкова ${ }^{1}$, директор \\ ${ }^{1}$ ТОВ «Млин База», м. Андрушівка Житомирськоӥ обл., Украӥна \\ Г.М. Станкевич², д-р техн. наук, професор \\ ${ }^{2}$ Одеська національна академія харчових технологій, м. Одеса, Украӥна
}

\title{
ПРАКТИЧНІ ПИТАННЯ ТЕХНОЛОГІЇ ЗБЕРІГАННЯ ЗЕРНА У ПОЛІМЕРНИХ ЗЕРНОВИХ РУКАВАХ
}

\begin{abstract}
Анотація
На підприємствах з обмеженими місткостями та малопотужним зерносушильним господарством існує проблема економного та надійного зберігання сухого, вологого і сирого зерна. Одним із варіантів ї̈ успішного розв'язання є застосування апробованої на багатьох підприємствах технології зберігання зерна в полімерних зернових рукавах (ПРЗ), основний принцип якої трунтується на самоконсервуванні зерна в герметичних умовах у середовищі вуглекислого газу. Для реалізації иієї технології необхідно на основі оперативного аналізу якості зерна визначити придатності партї зерна для завантаження в рукави, після завантаження зерна рукави герметизують, зернову масу зберігають певний час і потім вивантажують.

Після багаторічної промислової апробації технології зберігання зерна в ПзР були розроблені рекомендації, щзо дозволяють забезпечувати кількість та належну товарну якість зерна в прочесі реалізації вказаної технології. Для цього передбачається проведення цілого комплексу заходів - навчання персоналу, вибір та підготовка майданчик для зберігання зерна, дератизачія, визначення якості зерна на всіх етапах та безпечного терміну зберігання в залежності від стану зерна, зважування зерна; завантаження рукавів та розмімення їх на майданчику; нанесення позначення для ідентифікації рукавів; спостереження за станом ПРЗ $і$ зерна та відновлення иілісності рукавів на протязі всього терміну зберігання; облік зерна в рукавах; опрацювання некондиційного зерна; охорона об'єкта, підсумковий аналіз проведеної роботи, визначити проблем та шляхів їх розв'язання.

Майданчик для зберігання зерна в ПЗР повинен бути очищений від стерні і трави, гострих предметів, залишків зерна, мати тверде покриття або максимально ущільнений трунт (глиняна поверхня небажана, оскільки при осадках унеможливлюється закладання та вивантаження зерна), забезпечувати відсутність застоювання води підчас дощів і танення снігу, надавати можливість вільного руху спецтехніки по майданчику. Він повинен бути дератизований та огороджений сіткою з дрібними отворами, висотою не менше 1 м та прикопаною знизу.

Аналіз характеристик тришарових ПЗР показав, щзо для оптимізації зберігання сухого зерна доцільно використовувати найбільші рукави довжиною 90 м, оскільки вони мають більшу місткість, будуть менші витрати часу на одягання та запечатування рукавів, буде зекономитись площа між рукавами, щзо лежать
\end{abstract}


вздовж один за одного, буде менша довжина рукавів йти на зав'язування, а також буде економія коштів на вартості рукавів, вартості робочого часу та палива (зменшується кількість переїзів спецтехніки). Доцільно враховувати можливість розвантаження рукава впродовж однієї зміни.

На всіх етапах (завантаження, зберігання, вивантаження) щуотижнево визначають якість зерна, спостерігають за станом та відновлюють иілісність рукавів, перевіряють санітарний стан площадки та наявність приманок. Обов'язковим є охоронні заходи, облік зерна, робота з некондиційним зерном та підсумковий аналіз результатів зберігання зерна.

Ключові слова: зернова маса, полімерні зернові рукави, майданчик для зберігання, герметичні умови зберігання, якість зерна.

Надійшла 07.03.2019. Рецензія 29.04.2019.

До друку 07.06.2019.

Адреса для переписки:

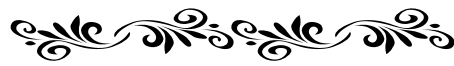

вул. Канатна, 112, м. Одеса, 65039

UDK [577.114.4:633.11]:57.0.13

${ }^{1}$ L.V. KAPRELYANTS, Dr. of tech. science, professor ${ }^{1}$ L.G. POZHITKOVA, PhD of tech. science, assistant, professor

${ }^{1}$ T. A. VELICHKO Dr. of tech. science, professor

${ }^{2}$ O. A. BILYK, PhD of tech. science, associate, professor

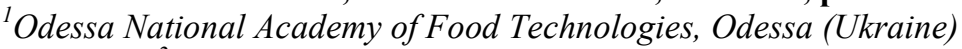

${ }^{2}$ National University of Food Technology, Kyiv (Ukraine)

\title{
WHEAT ARABINOXYLANS: STRUCTURE, EXTRACTION AND CHARACTERISTICS
}

\begin{abstract}
Wheat bran is a by-product of conventional milling and is commercially available in large quantities. Beside its high content of dietary fibre it contains proteins, minerals as well as vitamins and others biologically active components. In recent years, there have been designed different approaches to incorporation of wheat bran in food products to optimize composition or physiological effects. Industrial wheat bran is one of the most representative available hemicellulosic rich products. Arabinoxylans are the predominant non-starch polysaccharides found in the structural matrix of cell walls in wheat grains, being present in large quantities in wheat bran, accounting for up to 15-20\% of its composition.

Their physicochemical properties define their functionality which can be beneficial in cereal-based products such as bread, where their addition could enhance the gluten matrix responsible for the aerated structure and quality of bread. A potential source of arabinoxylans is its extraction from the wheat bran based low value as an end product of the milling process. The benefits of extraction are twofold, to enhance nutritional value wheat by-product reducing fibre content and produce a high value product for use as a functional ingredient in the bread making industry and in others foods. Extraction of arabinoxylans involves many possibilities for obtaining substances with different physicochemical properties, giving opportunity for integration in functional foods. Functional behaviour includes viscosity, water solubility, water holding capacity, oxidative cross linking and gel formation and foam stability, which are all reported to be affected by the physicochemical properties of arabinoxylans, as well as chain to chain interactions with other polymers and with the solvent.

Currently no commercial supply of arabinoxylans is available in sufficient quantities to conduct functionality trials; therefore the objective of the current work was to study the feasibility of extracting arabinoxylans from the bran for future developing and scaled-up extraction process based on the analyzed methods and approaches.

Keywords: arabinoxylans wheat, structure, classification, method of extraction, physicochemical properties, molecular weight, viscosity, water solubility.
\end{abstract}

Wheat is among the oldest grown of all crops. Nowadays, in terms of production, wheat ranks first among all cultivated plants. The estimated production of wheat in 2019 in Ukraine is 75 million tonnes, of which Triticum aestivum is the predominant species. The major use of wheat is for human consumption.

Wheat bran is a by-product of conventional milling and is commercially available in large quantities. Beside its high content of dietary fibre it contains proteins, minerals as well as vitamins and others biologically active components $[1,2]$.

Despite the presence of physiologically relevant nutrients, wheat bran is not a significant component of the human diet, but is mainly used as animal feed; high phytate content, brownish colour and gritty mouth-feel might limit acceptance as food. In recent years, there have been designed different approaches to incorporation of wheat bran in food products to optimize composition or physiological effects. Its use as a source of dietary fibre is indicated by epidemiological and experimental studies, which pointed to possible effects against colon cancer. Moreover, human intervention studies indicated that wheat bran, but not oat or corn bran, significantly decreased the levels of several tumour promoters in the colon [3].

Industrial wheat bran is one of the most representative available hemicellulosic rich products. The main hemicellulosic component is the arabinoxylans, 